УДК 543.422.3:615.453.6.074

DOI https://doi.org/10.11603/2312-0967.2021.1.11935

\title{
СПЕКТРОФОТОМЕТРИЧНЕ ВИЗНАЧЕННЯ АТЕНОЛОЛУ В ТАБЛЕТКАХ
}

\author{
О. Р. Малецька, С. О. Васюк
}

Запорізький державний медичний університет

elenamaletska@gmail.com

\section{ІНФОРМАЦІЯ}

Надійшла до редакції / Received: 13.01.2021

Після доопрацювання / Revised: 14.01.2021

Прийнято до друку / Accepted: 18.01.2021

\section{Ключові слова:}

атенолол;

діазоль червоний ЖЖ;

спектрофотометрія;

валідація.

\begin{abstract}
АНОТАЦІЯ
Мета роботи. Розробка та валідація методики спектрофотометичного визначення атенололу в лікарських препаратах.

Матеріали і методи. У роботі використовували такі реагенти і розчинники: діазоль червоний ЖЖ (НВФ «Синбіас»), таблетки «Атенолол-Астрофрарм» 50 мг (ТОВ «Астрофрарм», Україна, серія 050417), таблетки «АтенололАстрофрарм» 100 мг (ТОВ «Астрофрарм», Україна, серія 010218), метанол (LAB-SCAN, Ірландія, партія № 5120/13), натрій карбонат (НВФ «Синбіас»), вода дистильована.

Аналітичне обладнання: спектрофротометр «SPECORD-200» (Analytic Jena AG, Німеччина), ваги лабораторні електронні RADWAG XA 210.4Y, баня ультразвукова Sonorex Digitec DT100H, лабораторний посуд класу A.

Дослідження проводили у відділі експериментальних фрармацевтичних досліджень наукового медико-лабораторного центру (НМЛЦ) Запорізького державного медичного університету.

Результати й обговорення. Розроблено методику спектрофотометричного визначення кількісного вмісту атенололу за реакцією з діазолем червоним ЖЖ у середовищі вода-метанол. Методами насичення та неперервних змін встановлено стехіометричне співвідношення «атенолол - діазоль червоний ЖЖ»-1:1. Проведена валідація розробленої методики за такими критеріями, як лінійність, прецизійність, правильність та робасність. 3 огляду на отримані дані розроблена методика є коректною та може бути використана у відділах контролю якості хіміко-фрармацевтичних підприємств.

Висновки. Розроблено чутливу, економічну, просту у виконанні спектрофротометричну методику кількісного визначення атенололу в складі таблетованих лікарських форм «Атенолол-Астрафрарм» 50 мг та «АтенололАстрафрарм» 100 мг на основі реакції з діазолем червоним ЖЖ, яку було валідовано згідно зі стандартизованою процедурою валідації методом стандарту. Доведено, що за такими валідаційними характеристиками, як лінійність, прецизійність, правильність та робасність розроблена методика валідна та відповідає вимогам ДФУ.
\end{abstract}

Вступ. Атенолол - блокатор $\beta$-адренорецепторів, що має антиангінальний, антигіпертензивний та антиаритмічний ефректи. Зменшує автоматизм синусового вузла, уповільнює атріовентрикулярну провідність, знижує скоротливість міокарда і його потребу в кисні. Атенолол застосовують для лікування артеріальної гіпертензії, профрілактики нападів стенокардії, порушеннях серцевого ритму [1].

Згідно з Державною Фармакопеєю України і Британською Фармакопеєю, кількісний вміст атенололу в

ISSN 2312-0967. Фармацевтичний часопис. 2021. № 1 
субстанції визначають методом ацидиметрії з потенціометричним фріксуванням кінцевої точки титрування [2, 3]. Фармакопея США описує метод високоефрективної рідинної хроматограсрії (BЕРХ) 3 УФдетектором [4].

За даними літератури, для кількісного визначення атенололу в лікарських препаратах часто використовують абсорбційну спектрофотометрію в УФ- та видимій областях спектра. За сумісної присутності з іншими АФІ (наприклад, аторвастатином) атенолол у таблетках визначають методом абсорбційної спектрофотометрії в УФ-області за довжини хвилі 225 нм [5]. Запропоновано просту методику визначення атенололу в таблетках за реакцією з хлораніловою кислотою 3 утворенням комплексу з максимумом при 530 нм [6]. Наявність естерного угрупування в атенололі зумовлює утворення гідроксаматів фреруму (III) червоно-фріолетового кольору [7]. Описані методики спектросотометричного визначення атенололу за реакціями з бромтимоловим синім [8, 9], 2,3-дихлор1,4-нафртохіноном [10]. Вислоус О. А. зі співавторами розроблено екстракційно-оротометричну методику кількісного визначення атенололу за реакцією з метиловим оранжевим [11]. Akram M. El-Didamony описав ектракційно-фотометричну методику визначення низки $\beta$-адреноблокаторів за реакціями з бромкрезоловим зеленим і бромтимоловим синім [12].

Оскільки спектрофотометричні методи аналізу доступні, забезпечують точність, високу чутливість та відтворюваність результатів, розширення асортименту кольорореагентів для спектрофотометричного визначення АФІ є актуальним.

Тому метою роботи стала розробка точної, доступної та валідної спектрофротометричної методики кількісного визначення атенололу в лікарських орормах на основі реакції з діазолем червоним ЖЖ.

Матеріали і методи. Дослідження проводили на базі відділу експериментальних фрармацевтичних досліджень наукового медико-лабораторного центру (НМЛЦ) Запорізького державного медичного університету.

Об'єктом дослідження стали таблетки «АтенололАстрафрарм» 50 мг (ТОВ «Астрофрарм», Україна, серія 050417), таблетки «Атенолол-Астрафрарм» 100 мг (ТОВ «Астрофрарм», Україна, серія 010218).

Як аналітичний органічний реагент застосовували барвник діазоль червоний ЖЖ (НВФ «Синбіас»).

В експериментальній частині використовували розчинники класифікації «ч.д.а.» та «х.ч.»: ацетон, метанол, етанол, ізопропанол, вода.

При виконанні дослідження застосовували таке обладнання: спектрофротометр «SPECORD-200» (Analytic Jena AG, Німеччина), ваги лабораторні електронні RADWAG XA 210.4Y, ультразвукову баню Sonorex Digitec DT100H., мірний посуд класу A.

Вимірювання абсорбції проводили у видимій області спектра в прямокутних кварцових кюветах із товщиною шару 1 см на фроні компенсаційного розчину. Для обробки спектрів використовували програмний пакет WinASPECT 2.2.1.0. Для побудови графріків та розрахунку параметрів лінійної залежності застосовували програму «Sigma Plot 12.5». Статистичну обробку та визначення валідаційних характеристик проводили згідно з вимогами ДФУ.

Загальна методика визначення атенололу

Приготування розчину порівняння атенололу: 0,03400 г атенололу вміщують до мірної колби на 100,00 мл, розчиняють у метанолі та доводять метанолом до позначки, перемішують.

Приготування компенсаційного розчину: 1,00 мл 0,2 \% розчину діазолю червоного ЖЖ в метанолі переносять до мірної колби на 10,00 мл, додають 0,20 мл 0,1 \% розчину натрій карбонату, витримують 15 хв, додають 2,00 мл метанолу, доводять водою до позначки та перемішують.

Аліквотну частину атенололу (0,02494-0,06026 г) вміщують до мірної колби на 10,00 мл, додають 1,00 мл 0,2 \% розчину діазолю червоного ЖЖ у метанолі, 0,20 мл 0,1\% розчину натрій карбонату, витримують 15 хв, додають 2,00 мл метанолу, доводять водою до позначки та перемішують. Вимірюють абсорбцію отриманого розчину на фоні компенсаційного розчину за аналітичної довжини хвилі 377 нм.

\section{Визначення атенололу в таблетках}

Точну наважку ретельно розтертої таблеткової маси (близько 0,2 г) «Атенолол-Астрафрарм» 50 мг, (близько 0,14 г) «Атенолол-Астрофрарм» 100 мг, переносять до мірної колби на 100,00 мл, доводять метанолом до позначки, витримують в ультразвуковій бані впродовж 2 хв. Після цього розчин фрільтрують через паперовий фрільтр («Синя стрічка»), відкидаючи перші порції фрільтрату. 3 наступних порцій фрільтрату беруть 1,00 мл розчину, переносять до мірної колби на 10,00 мл, додають 1,00 мл 0,2 \% розчину діазолю червоного ЖЖ в метанолі, 0,20 мл 0,1 \% розчину натрій карбонату, витримують 15 хв, додають 2,00 мл метанолу, доводять водою до позначки та перемішують. Вимірюють абсорбцію забарвлених розчинів на фроні компенсаційного розчину за аналітичної довжини хвилі 377 нм. Паралельно проводять дослід 3 1,00 мл розчину порівняння атенололу. Розрахунок вмісту діючої речовини проводять за загальноприйнятою формулою.

Результати й обговорення. На етапі розробки методики кількісного визначення атенололу за реакцією 3 діазолем червоним ЖЖ вивчено чинники, які впливають на вихід продукту реакції: розчинник, кількість реагенту, час перебігу реакції та стабільність аналізованих розчинів у часі.

Розчинник обирали враховуючи розчинність атенололу та діазолю червоного ЖЖ, а також максимальну величину абсорбції. Кількість реагенту також обирали за максимальним значенням абсорбції.

ISSN 2312-0967. Pharmaceutical review. 2021. № 1 


\section{Analysis of drugs}

Експериментальним шляхом встановлено, що реакція перебігає у водно-метаноловому середовищі за кімнатної температури з використанням 0,2 \% розчину діазолю червоного ЖЖ як кольорореагента за присутності 0,1 \% розчину натрій карбонату з утворенням забарвленого продукту реакції з максимумом світлопоглинання при 377 нм (рис. 1).

Наступним етапом дослідження було встановлення кількості реагенту, необхідного для повноти перебігу реакції. ІІї встановлювали експериментально, за максимальною величиною оптичної густини. Для цього до мірних колб на 10,00 мл переносили по 1,00 мл розчину досліджуваної лікарської речовини та по 0,50; 1,00; 1,50; 2,00 та 2,50 мл реагенту. Абсорбцію досліджуваних розчинів вимірювали на фоні компенсаційних розчинів при обраній вище довжині хвилі.

На наступному етапі дослідження досліджено стабільність аналізованого розчину в часі. Для цього ви- мірювали абсорбцію отриманого розчину в оптимальних умовах впродовж 45 хв 3 інтервалом у 5 хв. Встановлено, що досліджувані розчини стабільні впродовж щонайменше 45 хв. Як приклад наводимо грасрік залежності абсорбції продуктів реакції атенололу з діазолем червоним ЖЖ від часу (рис. 2).

Стехіометричні коефіцієнти між атенололом та діазолем червоним ЖЖ встановлювали методом неперервних змін (методом ізомолярних серій) та методом насичення (методом молярних співвідношень) [13].

Метод ізомолярних серій ґрунтується на визначенні співвідношень ізомолярних концентрацій реагуючих речовин, що відповідає максимальному виходу сполук, що утворюються в результаті реакції. Для виконання аналізу готували розчини реагенту та досліджуваної лікарської речовини однакової молярної концентрації $(0,0012$ M) та змішували їх в антибатних

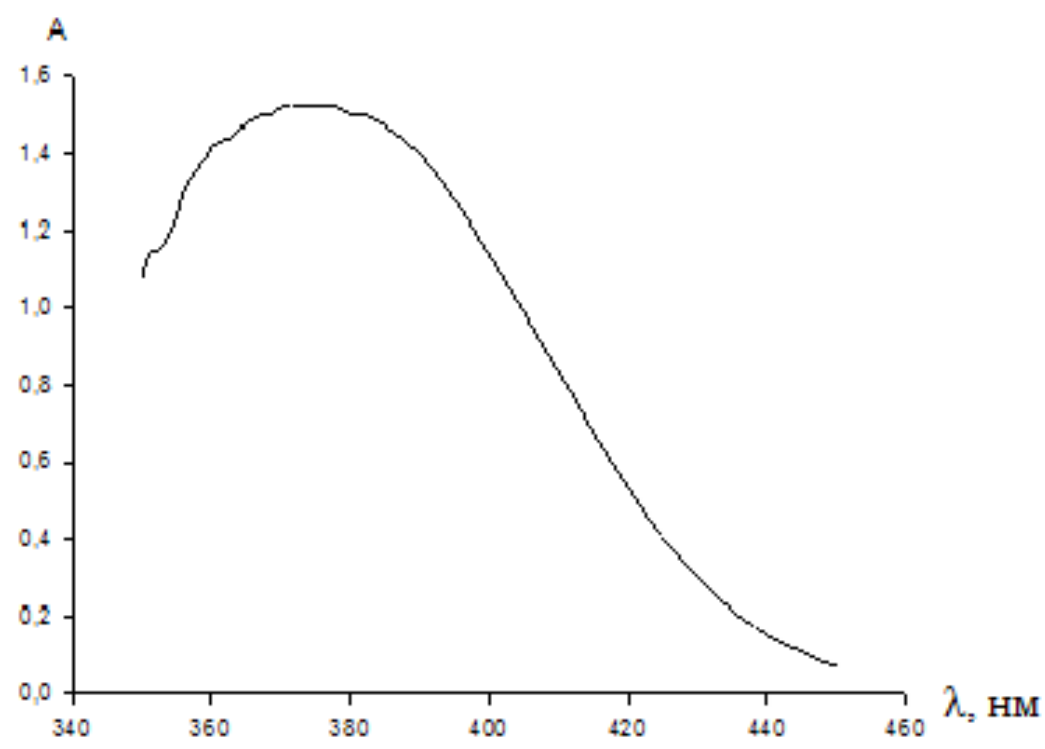

Рис. 1. Спектр поглинання продукту реакції атенололу з діазолем червоним ЖЖ.

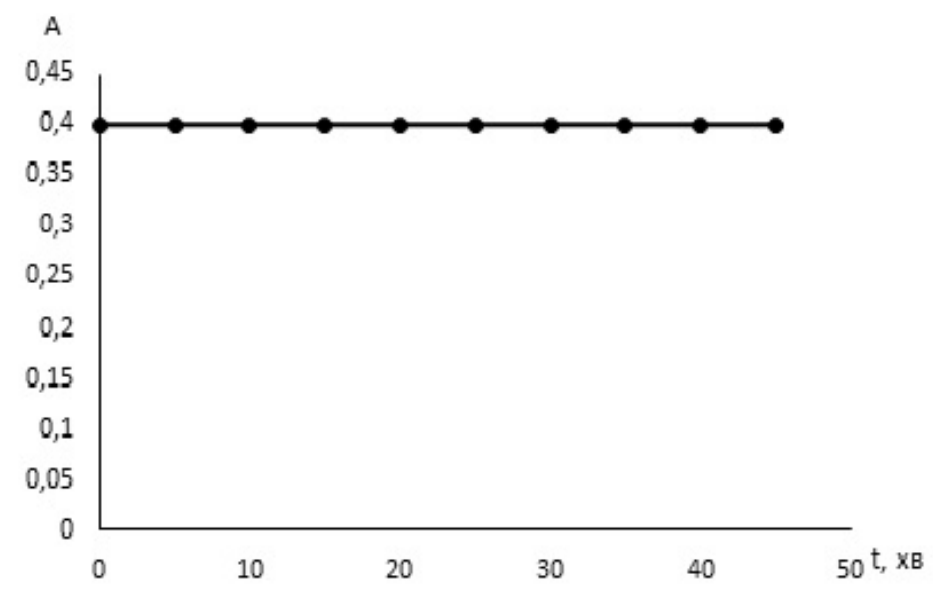

Рис. 2. Грасрік залежності абсорбції продукту реакції атенололу з діазолем червоним ЖЖ у водно-метаноловому розчині від часу.

ISSN 2312-0967. Фармацевтичний часопис. 2021. № 1 
співвідношеннях, загальний об'єм розчину при цьому лишається незмінним. Реакцію проводили згідно 3 розробленою методикою. За отриманими даними будували графік залежності величини абсорбції від співвідношення об'ємів компонентів ізомолярних серій (рис. 3).

Метод молярних співвідношень встановлює залежність абсорбції від концентрації одного з компонентів реакційної суміші при постійній концентрації другого компоненту та навпаки. Точка перегину на кривій насичення дорівнює стехіометричному коефіцієнту компонента, концентрація якого змінювалась (рис. 4, 5).
За даними рисунків 3-5, стехіометричні співвідношення реагуючих компонентів «атенолол - діазоль червоний ЖЖ», одержані за обома методами, погоджуються між собою і становлять 1:1.

\section{Визначення валідаційних характеристик}

Відповідно до вимог Державної Фармакопеї України, методики кількісного визначення лікарських препаратів повинні бути валідовані. Валідація методик кількісного аналізу лікарських препаратів є основною умовою забезпечення надійності результатів аналізу. Тому для перевірки коректності запропонованої методики були визначені основні валідаційні характеристики, а саме: ліній-

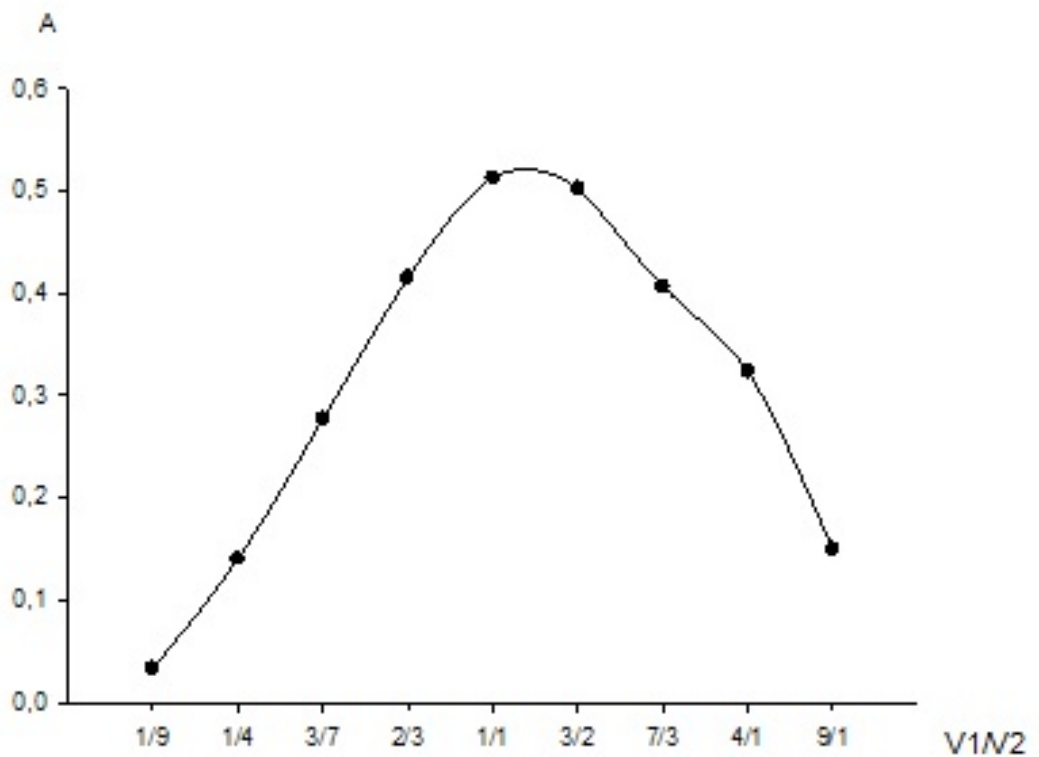

Рис. 3. Грасрік залежності величини абсорбції від складу ізомолярного розчину (V1 - 0.0012 М розчин атенололу, V2 - 0,0012 М розчин діазолю червоного ЖЖ) при 377 нм.

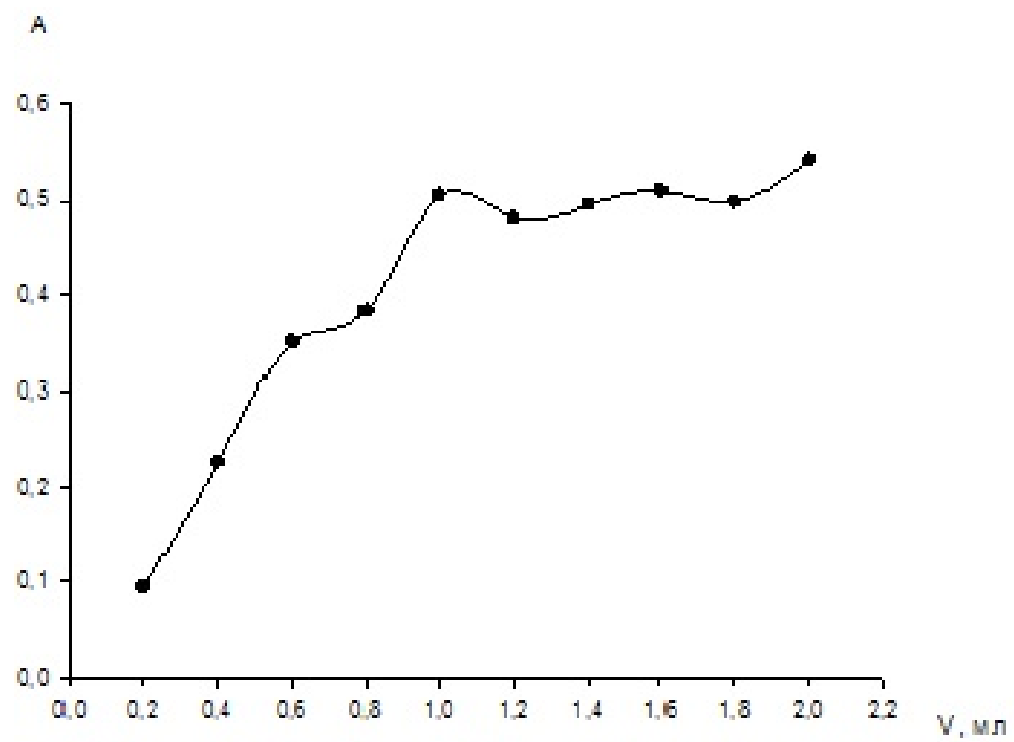

Рис. 4. Крива насичення розчину атенололу при постійній концентрації розчину реагенту.

ISSN 2312-0967. Pharmaceutical review. 2021. № 1 
Analysis of drugs

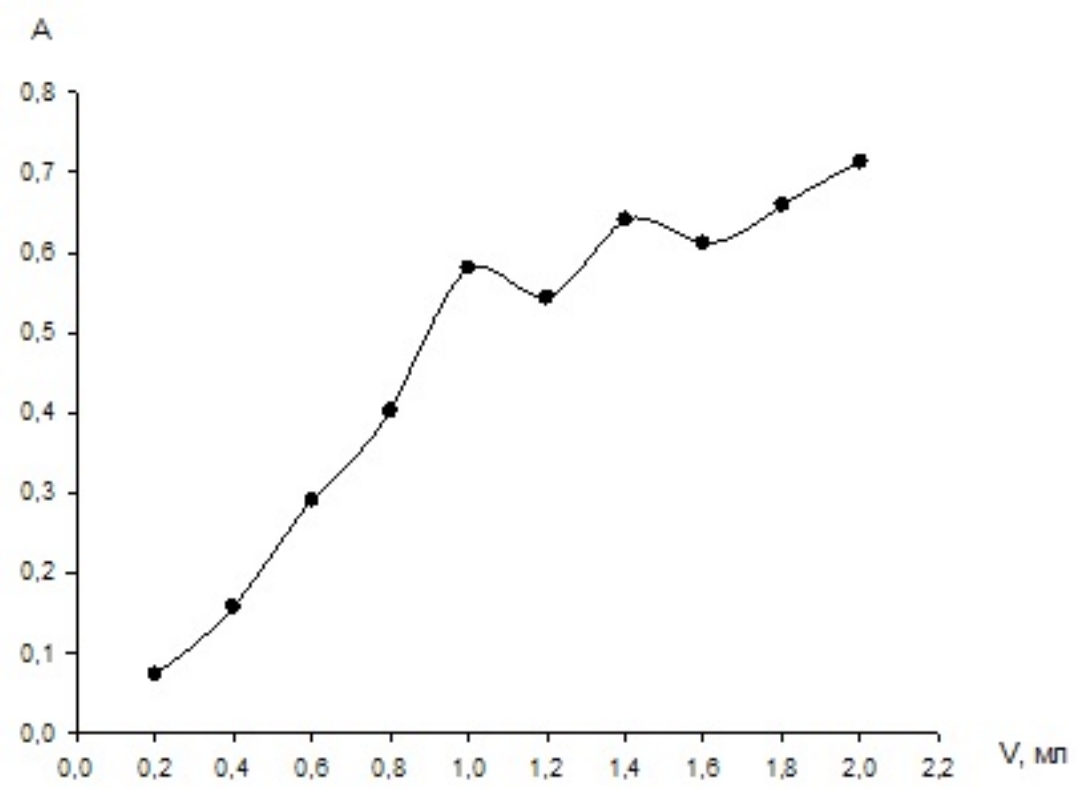

Рис. 5. Крива насичення розчину реагенту при постійній концентрації розчину атенололу.

ність, прецизійність, правильність та робасність $[2,14]$.

\section{Лінійність та діапазон застосування}

Лінійна залежність оптичної густини від концентрації досліджуваної речовини лежить в межах 2,64,2 мг/100 мл. Розчини 3 відомою концентрацією отримували шляхом розведення стандартного 0,034 \% розчину атенололу і вимірювали абсорбцію при 377 нм. За отриманими результатами було побудовано графрік залежності абсорбції від концентрації атенололу в нормалізованих координатах (рис. 6).
Параметри лінійної залежності розраховували за допомогою регресійного аналізу методом найменших квадратів. Одержані величини: коефіцієнти b i a, стандартні відхилення для b i a $-\mathrm{S}_{\mathrm{b}}$ i $\mathrm{S}_{\mathrm{a}}$, відносне залишкове стандартне відхилення за віссю абсцис $\mathrm{S}_{\mathrm{x}, 0}(\%)$ і коефріцієнт кореляції $\mathrm{r}$ наведено в таблиці 1 .

Таким чином, з огляду на отримані дані, лінійність методики підтверджується у всьому зазначеному інтервалі, а діапазон застосування методики складає 76-124 \% від номінальної концентрації атенололу.

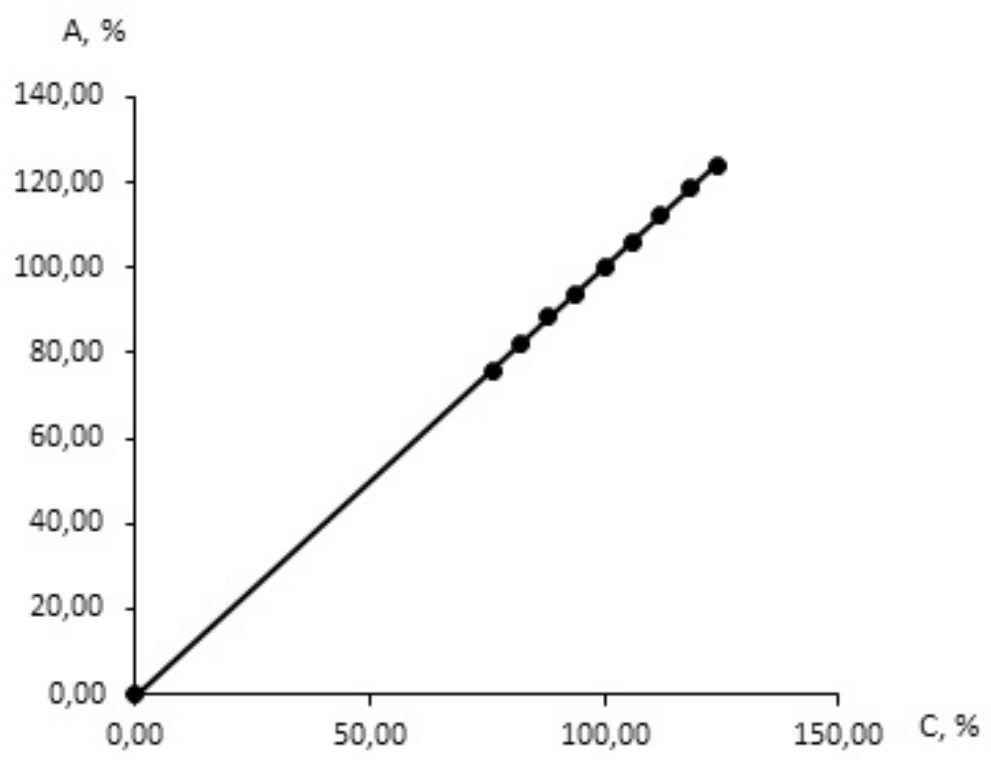

Рис. 6. Грасрік залежності абсорбції від концентрації атенололу.

ISSN 2312-0967. Фармацевтичний часопис. 2021. № 1 
Аналіз лікарських засобів Analysis of drugs

Таблиця 1

Оптичні характеристики та основні параметри лінійної залежності реакції атенололу з діазолем червоним ЖЖ

\begin{tabular}{|l|c|}
\hline Молярний показник поглинання, $\varepsilon$ & 11031,80 \\
\hline Коесіцієнт Сендела, $\mathrm{W}_{\mathrm{s}}$ & 0,024 \\
\hline Відкривальний мінімум, Сmin, (мкг/мл) & 12,07 \\
\hline Рівняння лінійної регресії & $\mathrm{Y}=\mathrm{bX}+\mathrm{a}$ \\
\hline Кутовий коесріцієнт, $\mathrm{b} \pm\left(\mathrm{S}_{\mathrm{b}}\right)$ & $1,0059( \pm 0,0045)$ \\
\hline Вільний член лінійної регресії, $\mathrm{a} \pm\left(\mathrm{S}_{\mathrm{a}}\right)$ & $0,4344( \pm 0,4580)$ \\
\hline Залишкове стандартне відхилення, $\mathrm{S}_{\mathrm{x}, 0}$ & 0,103 \\
\hline Коесріцієнт кореляції, $\mathrm{r}$ & 0,9999 \\
\hline
\end{tabular}

\section{Прецизійність}

Прецизійність було визначено на рівні збіжності. Для цього для лікарської фрорми було проведено дев'ять визначень, які охоплюють діапазон застосування методики (три концентрації/три визначення для кожної). Абсорбцію розчину порівняння вимірювали паралельно. Вміст атенололу в складі лікарських форм розраховували за загальноприйнятою формулою. За отриманими результатами розраховували метрологічні характеристики (табл. 2). В усіх випадках однобічний довірчий інтервал $\Delta_{z}$ не перевищує максимально припустиму невизначеність аналізу $\Delta_{A S}$, тому методика $€$ точною на рівні збіжності.

\section{Правильність}

Правильність було встановлено методом добавок. Для цього до трьох рівних проб лікарської форми до- давали різну кількість розчину порівняння атенололу та аналізували тричі. За даними таблиці 3, розраховані критерії практичної незначущості для лікарських фрорм не перевищують максимально допустиму невизначеність аналізу.

\section{Робасність}

Оцінку робасності проводять на стадії розробки методики. Ця оцінка має довести надійність результатів аналізу при невеликих змінах параметрів методики. Оцінювали параметри, які можуть вплинути на величину абсорбції: стабільність аналізованих розчинів у часі та кількість доданих реагентів.

Було встановлено, що аналізовані розчини стабільні впродовж щонайменше 45 хв, а коливання кількості доданих реагентів у межах $\pm 10 \%$ суттєво не впливає на величину оптичної густини.

Таблиця 2

Визначення прецизійності результатів кількісного визначення атенололу в таблетках

\begin{tabular}{|l|c|c|c|c|}
\hline \multicolumn{1}{|c|}{ Лікарська фрорма } & $\bar{Z} \%(\mathrm{n}=9)$ & $\mathrm{S}_{\mathrm{z}} \%$ & $\Delta_{\text {AS }}$ & $\Delta_{z}$ \\
\hline «Атенолол-Астрофрарм» $50 \mathrm{мг}$ & 99,69 & 0,5128 & 1,6 & 0,9538 \\
\hline «Атенолол-Астрофрарм» $100 \mathrm{мг}$ & 99,67 & 0,8353 & 1,6 & 1,5537 \\
\hline
\end{tabular}

Таблиця 3

Визначення правильності результатів кількісного визначення атенололу в таблетках

\begin{tabular}{|l|c|c|c|c|}
\hline \multicolumn{1}{|c|}{ Лікарська фрорма } & $\overline{\mathrm{Z}} \%(\mathrm{n}=9)$ & $\mathrm{S}_{z} \%$ & $\Delta_{z}$ & $\overline{\mathrm{Z}}-100$ \\
\hline «Атенолол-Астрафрарм» 50 мг & 99,95 & 2,81 & 5,22 & 0,05 \\
\hline «Атенолол-Астрофрарм» 100 мг & 99,38 & 1,16 & 2,16 & 0,62 \\
\hline
\end{tabular}

Висновок. Розроблено чутливу, економічну спектрофотометричну методику кількісного визначення атенололу в складі таблетованих лікарських фрорм «Атенолол-Астрафрарм» 50 мг та «Атенолол-Астрафрарм» 100 мг на основі реакції з діазолем червоним ЖЖ, яку було валідовано згідно зі стандартизованою процедурою валідації методом стандарту.
Доведено, що за такими валідаційними характеристиками, як лінійність, прецизійність, правильність та робасність розроблена методика валідна та відповідає вимогам ДФУ.

Конфлікт інтересів: відсутній.

Conflicts of interest: authors have no conflict of interest to declare.

ISSN 2312-0967. Pharmaceutical review. 2021. № 1 
Аналіз лікарських засобів

\title{
Analysis of drugs \\ SPECTROPHOTOMETRIC DETERMINATION OF ATENOLOL IN TABLETS
}

\author{
O. R. Maletska, S. O. Vasyuk \\ Zaporizhzhia State Medical University \\ elenamaletska@gmail.com
}

The aim of the work. Develop a method for spectrophotometric determination of atenolol with diazonium salts; establish optimal conditions for the quantitative determination of atenolol in drugs; validate the developed methodology.

Materials and Methods. All studies were conducted on the basis of the Experimental Pharmaceutical Research Department of the Scientific Medical Laboratory Center (NMLC) of the Zaporizhzhia State Medical University.

Reagents and solvents used in the present study: diazole red (obtained from NVF "Sinbias"), tablets "Atenolol-Astropharm" 50 mg (LLC "Astropharm", Ukraine, series 050417) and "Atenolol-Astropharm" 100 mg (LLC "Astrofarm" Ukraine, series 010218). Methanol (LAB-SCAN, Ireland, batch No 5120/13), sodium carbonate (Sinbias) and distilled water were also used. Analytical equipment: Spectrophotometer "SPECORD-200" (Analytic Jena AG, Germany), scales laboratory electronic RADWAG XA 210.4Y, bath ultrasonic Sonorex Digitec DT100H, laboratory glassware of class A.

Results and Discussion. The technique of spectrophotometric determination of the quantitative content of atenolol based on its reaction with red diazole in water-methanol medium has been developed. The stoichiometric ratios of the reactive components as 1:1 were obtained by the methods of continuous changes and the saturation method. Validation of the developed on such indicators as linearity, precision, correctness and robustness is carried out. Based on these data, the developed method is correct and can be used in the quality control departments of chemical and pharmaceutical companies. Conclusions. A method of quantitative spectrophotometric determination of atenolol in the tablet dosage form "AtenololAstrapharm" $50 \mathrm{mg}$ and "Atenolol-Astrapharm" $100 \mathrm{mg}$ of industrial production was developed, validation characteristics were investigated: linearity, precision, correctness, range of application and robustness.

Key words: atenolol; diazonium salts; spectrophotometry; validation.

\section{СПЕКТРОФОТОМЕТРИЧЕСКОЕ ОПРЕДЕЛЕНИЕ АТЕНОЛОЛА В ТАБЛЕТКАХ}

\section{Е. Р. Малецкая, С. О. Васюк}

\section{Запорожский государственный медицинский университет} elenamaletska@gmail.com

\begin{abstract}
Цель роботы. Разработка и валидация методики спектрофотометрического определения атенолола в лекарственных препаратах.

Материалы и методы. В работе использовали следующие реагенты и растворители: диазоль красный жЖ (НВФ «Синбиас»), таблетки «Атенолол-Астрофрарм» 50 мг (ТОВ «Астрофрарм», Украина, серия 050417), таблетки «Атенолол-Астрофарм» 100 мг (ТОВ «Астрофарм», Украина, серия 010218), метанол (LAB-SCAN, Ирландия, партия № 5120/13), натрия карбонат (НВФ «Синбиас»), вода дистиллированная.

Аналитическое оборудование: спектрофотометр «SPECORD-200» (Analytic Jena AG, Германия), весы лабораторные электронные RADWAG XA 210.4Y, баня ультразвуковая Sonorex Digitec DT100H, лабораторная посуда класса A. Исследование проводилось в отделе экспериментальных фармацевтических исследований научного медиколабораторного центра (НМЛЦ) Запорожского государственного медицинского университета.

Результаты и обсуждение. Разработана методика спектрофотометрического определения количественного содержания атенолола по реакции с диазолем красным ЖЖ в среде вода-метанол. Методами насыщения и непрерывных изменений установлено стехиометрическое соотношение «атенолол - диазоль красный жЖ» 1:1. Проведена валидация разработанной методики за такими критериями, как линейность, прецизионность, правильность и робастность. Исходя из полученных данных, разработанная методика является корректной и может быть использована в отделах контроля качества химико-срармацевтических предприятий.

Выводы. Разработана чувствительная, экономичная, простая в выполнении спектрофотометрическая методика количественного определения атенолола в составе таблетированных лекарственных фрорм «АтенололАстрасрарм» 50 мг и «Атенолол-Астрафарм» 100 мг на основе реакции с диазолем красным ЖЖ, которая была валидирована согласно стандартизированной процедуре валидации методом стандарта. Доказано, что за такими валидационными характеристиками, как линейность, прецизионность, правильность и робастность разработанная методика валидна и отвечает требованиям ГФУ.
\end{abstract}

Ключевые слова: атенолол; диазоль красный ЖЖ; спектросротометрия; валидация.

ISSN 2312-0967. Фармацевтичний часопис. 2021. № 1 


\section{Список бібліографрічних посилань}

1. Компендіум. Лікарські препарати. URL: https://compendium.com.ua.

2. Державна Фармакопея України. 2-е вид. X. : Державне підприємство «Науково-експертний фрармакопейний центр», 2015. Т 1. 2015. 1128 с.

3. British Pharmacopeia. Vol. 1-4. London: The Stationary Office, 2009. 10952.

4. United States Pharmacopeia 36. USP Convention Inc. Rockville, 2013. 5640.

5. Dey S., Sarkar S., Malakar J. Spectrophotometric method for simultaneous determination of atenolol and atorvastatin in tablet dosage forms. Int. J. Pharm. Biomed. Res. 2012. Vol. 3, No. 1. P. 40-43.

6. Yu L. L., Liu J. C., Li H. K. Spectrophotometry determination of atenolol in tablets based on charge transfer complex of atenolol with chloranilic acid. Yaowu Fenxi Zazhi. 2010. Vol. 30, No. 3. P. 538-540.

7. Количественное определение атенолола в таблетках Тонорма методом спектрофотометрии / Вислоус О. А., Бевз Н. Ю., Живора Н. В., Безуглый П. А. Вестник фрармации. 2014. № 4 (66). С. 68-73.

8. Zhuk Y. N., Vasyuk S. O. Quantitative determination of Atenolol in tablets. IJAPBC. 2015. Vol. 5, No 3. P. 350-354.

9. Жук Ю. М. Спектрофотометричне визначення деяких $\beta$-адреноблокаторів в лікарських фрормах /

\section{References}

1. Compendium. 2021. Directory of drugs Compendium. [Internet] Available at: <https://compendium.com.ua>.

2. State Pharmacopoeia of Ukraine. 2nd type. [Державна Фармакопея України. 2е вид.] Kharkiv: State Enterprise "Scientific and Expert Pharmacopoeial Center"; 2015. Ukrainian.

3. British Pharmacopeia. London: The Stationary Office; 2009.

4. United States Pharmacopeia. Rockville: USP Convention Inc; 2013.

5. Dey S, Sarkar S, Malakar J. Spectrophotometric method for simultaneous determination of atenolol and atorvastatin in tablet dosage forms. International Journal of Pharmaceutical and Biomedical Research. 2012;1(3): 40-43.

6. Yu LL, Liu JC, Li HK. Spectrophotometry determination of atenolol in tablets based on charge transfer complex of atenolol with chloranilic acid. Yaowu Fenxi Zazhi. 2010;3(30): 538-40.

7. Wislous OA, Bevz NYu, Zhivora NV, Bezugly PA. Quantitative determination of atenolol in Tonorm tablets by spectrophotometry. Journal of Pharmacy. 2014;4 (66): 68-73.

8. Zhuk YN, Vasyuk SO. Quantitative determination of Atenolol in tablets. IJAPBC. 2015;5(3): 350-4.

9. Zhuk Y. Spectrophotometric determination of some
Матеріали XVVII Міжнародного медичного Конгресу студентів і молодих вчених. 2013. С. 1.

10. Донченко А. О., Васюк С. О. Спектрофотометричне визначення атенололу в лікарських фрормах із використанням 2,3-дихлор-1,4-нафтохінону. Фармачевтичний часопис. 2017. № 4. С. 63-68.

11. Віслоус О. О., Бевз Н. Ю., Георгіянц В. А. Метод ідентифрікації та кількісного визначення $\beta$-адреноблокаторів (огляд літератури). Scientific Journal «ScienceRise». 2015. № 10/4 (15). C. 56-70.

12. Akram M. El-Didamony, Didamony, Sameh M. Hafeez, Ahmed A. Saad. Application of bromocresol green and bromothymol blue for the extractive spectrophotometric determination of anti-hypertensive drugs. Journal of Applied Pharmaceutical Science. 2015. Vol. 5. No. 7. P. 122-129.

13. Булатов М. И., Калинкин И. П. Практическое руководство по фотометрическим методам анализа. Изд. 5-е. Л. : Химия, 1986. 432 с.

14. Гризодуб А. И. Стандартизованные процедуры валидации методик контроля качества лекарственных средств. Х. : Государственное предприятие «Украинский научный фрармакопейный центр качества лекарственных средств», 2016. 396 c.

$\beta$-blockers in dosage forms. Proceedings of the 67th International Medical Congress of Students and Young Scientists. Kyiv; 2013. Ukrainian.

10. Donchenko AA., Vasyuk SO. Spectrophotometric determination of atenolol in dosage forms using 2,3-dichloro-1,4-naphthoquinone. Pharmaceutical Journal. 2017;4: 63-8.

11. Wislous OO, Bevz NYu, Georgiyants VA. Method of identification and quantification of $\beta$-blockers (literature review). Scientific Journal «ScienceRise». 2015;10/4(15): 56-70. Ukrainian.

12. Akram MEl-Didamony. Application of bromocresol green and bromothymol blue for the extractive spectrophotometric determination of anti-hypertensive drugs. Journal of Applied Pharmaceutical Science. 2015;7(5): 122-9.

13. Bulatov MI, Kalinkin IP. Practical guide to photometric methods of analysis. 5th ed. [Практическое руководство по фоотометрическим методам анализа, 5-е изд.] Leningrad: Chemistry; 1986. Russian.

14. Grizodub Al. Standardized procedures for validation of methods of quality control of medicines. [Стандартизованные процедуры валидации методик контроля качества лекарственных средств.] Kharkiv: State Enterprise «Ukrainian Scientific Pharmacopoeial Center for Drug Quality»; 2016. Russian. 


\section{Analysis of drugs \\ Відомості про авторів}

Малецька О. Р. - асистент кафедри аналітичної хімії, Запорізький державний медичний університет, Запоріжжя, Україна. E-mail: elenamaletska@gmail.com, ORCID 0000-0001-6854-1952.

Васюк С. О. - д. фрармац. наук, професор, завідувач кафедри аналітичної хімії, Запорізький державний медичний університет, Запоріжжя, Україна. E-mail: svitlanavasyuk@gmail.com, ORCID 0000-0002-1569-9374.

\section{Information about the authors}

Maletska O. R. - assistant of Analytical Chemistry Department, Zaporizhzhia State Medical University, Zaporizhzhia, Ukraine. E-mail: elenamaletska@gmail.com, ORCID 0000-0001-6854-1952.

Vasyuk S. O. - DSc (Pharmacy), Chief of the Analytical Chemistry Department, Zaporizhzhia State Medical University, Zaporizhzhia, Ukraine. E-mail: svitlanavasyuk@gmail.com, ORCID 0000-0002-1569-9374. 